\title{
De-universalizing the decolonial: between parentheses and falling skies
}

\author{
Lynn Mario Trindade Menezes de Souza ${ }^{\mathrm{a}}$ (D) \\ Ana Paula Martinez Duboc (D)
}

\begin{abstract}
Departing from the premise that decoloniality is growing in popularity within contemporary Brazilian Applied Linguistics studies, this paper claims in favor of a more performative decolonial praxis so as to prevent decoloniality from universality. In doing so, the text begins with some theorizations on decolonial thought with an emphasis on the triad fundamental in any decolonial exercise, that is to Identify-Interrogate-Interrupt coloniality. The paper, then, claims in favor of thinking communication otherwise which, along with the notions of bringing back the body and marking the unmarked, constitute the necessary decolonial strategies if one wishes to interrupt coloniality. A critical examination of The falling Sky: words of a Yanomami shaman, co-authored by Kopenawa and Albert (2013), is brought to the fore as illustrative of a decolonial pedagogy which attempts to help language teacher educators and researchers to become attentive to socially-just-oriented educational agendas that claim to be culturally-sensitive whereas, in fact, they may be serving the purposes of a still prevailing colonial project.
\end{abstract}

Keywords: Decoloniality. De-universalization. Think communication otherwise.

\footnotetext{
aUniversidade de São Paulo, Faculdade de Filosofia, Letras e Ciências Humanas, São Paulo, SP, Brazil.

E-mail: lynnmario@gmail.com

'Universidade de São Paulo, Faculdade de Educação, São Paulo, SP, Brazil. E-mail: anaduboc@usp.br
}

\section{How to cite:}




\section{Introduction}

Decolonial futures don't have words yet; they don't have a "how": How would these networks of exchange of people thinking and living against coloniality be formed? What are the conditions of possibility of this pluriversal movement? Would it be necessary to establish conditions for these dialogues? Among whom would they be? Would they include the oppressor? What languages would be spoken? How would nonverbalized knowledge be recognized? The call for plurality and critical intercultural dialogue is there; the idea of pluriversality is there. It is a nice idea. The question is how to go about it. Is it necessary to decolonize dialogue itself? (VERONELLI, 2016, p. 405)

We begin this text by affirming where we are speaking from. Firstly, we speak from a dire context of the coronavirus pandemic, which this week surpassed the mark of 500,000 deaths. Both of us are faculty in the areas of Applied Linguistics and Education, with interests in decolonial theory, and literacy in general, considered to be peripheral to the hegemonic areas of interest in our respective areas. Both of us speak from the experience of being colonized. One of us speaks, in addition, from a life-experience of being non-white, whereas the other speaks from the position of being a woman, a mother and a professional in a patriarchal culture. We don't claim to speak from the peripheries of our own cultures, but we are acutely aware of our location in the global south.

In her discussion on the current status and the future of decoloniality, Veronelli (2016) calls for a nondialogical theory of communication if one wishes to decolonize dialogue itself. The difficulties posed by the author are worth pinpointing here: whereas we sometimes advance in theoretical discussions, we lack alternatives that would allow us to change the terms of the conversation and, ultimately, change the course of history.

In our discussion, we problematize dialogue and intercultural dialogue in relation to pedagogies. By assuming that i) many of us in language teaching are still mesmerized by the fetish of method that has historically marked most language teaching approaches and; ii) decoloniality has rapidly grown in popularity in Brazilian Applied Linguistics, we, call for an attentive and critical awareness with regards to the intersections between decoloniality and language 
education so as to prevent the field from the tempting nature of methodologization. We propose that before (or together with) practice and implementation, time must be taken to appreciate certain concepts of decolonial theory; here we consider praxis as practice with conceptual reflection.

As a matter of fact, emphasis on praxis seems to be one of the tenets in decolonial thought. The Modernity/Coloniality school emerged back in the 1990s and early 2000s from the work of Latin-American authors (CASTRO-GOMEZ, 2005; DUSSEL, 2012; GROSFOGUEL, 2013; MIGNOLO, 2009, 2018, 2019; QUIJANO, 2005; WALSH, 2007, 2012 to name a few), who begin to question Eurocentric knowledge production. Broadly speaking, their claim on the need to enunciate about and from the perspective of global south epistemologies is founded on two aspects: one is chronological/historical and the other is spatial/geographic.

In relation to the aspect of chronology/history, decoloniality departs from the premise that there is no linear history nor autonomous or independent cultures despite the fiction of linearity and homogeneity created by Modernity. Grosfoguel (2013) cites four genocides/epistemicides committed by the West since the $16^{\text {th }}$ century founded on the logic of ego conquiro or "I exterminate, therefore I am" on which is based the later cartesian logic of ego cogito "I think, therefore I am", so much valorized by Western Modernity which we have inherited in Brazil, and which permeates our current academy and its pedagogies. This is a reminder of the extreme violence on which the primacy of modern science and its over-estimated objectivity is based.

In relation to the spatial/geographic aspect, Dussel (2000) reminds us that European Modernity, despite appearances and its own claims, was not created solipsistically. It is mutually constituted by its alterity - the colonized that it excluded. In order to perceive this, it is necessary to take into consideration perception and location which produce perspective. The world cannot be seen from a God's eye perspective. It is always seen from a situated perspective and thus has a specific locality. The erased situated perspective of coloniality generates what Castro-Gómez (2005) called la hybris del punto cero or the belief of Western coloniality that its knowledge was the one and only mode of knowing, hence producing the illusion of universality. 
Connecting this with Grosfoguel's previously mentioned ego conquiro as the basis of ego cogito, once again it becomes possible to perceive the violence behind the illusion of the universality of knowledge.

In order to recuperate the spatial/geographic aspect of the coloniality of knowledge, it becomes necessary to undo the illusion of universality and the appearance of knowledge produced from nowhere. This accompanies the need to also undo the illusion of knowledge produced by no body, the other aspect of the production of what absurdly purports to be universal knowledge - the knowledge produced nowhere by no body. From Dussel's emphasis on location as a decolonial strategy, and Grosfoguel's notion of the concealed body in the much-valued cartesian rationality, we develop the notions of bringing the body back and marking the unmarked (SOUZA, 2019a, $2019 \mathrm{~b}$ ) as decolonial strategies. These in turn constitute part of a proposed decolonial pedagogy involving the interconnected triad Identify-Interrogate-Interrupt (SOUZA 2019a, 2019b).

According to Grosfoguel (2013), the historic colonial ego conquiro differs from the modern colonial ego cogito by concealing the body that produces knowledge, thus separating what is said from the enunciating subject. This separation allows for the illusion of universality and unmarked-ness to the extent that what is enunciated, unanchored from a particular, situated location, appears to have universal value and meaning. The proposed decolonial strategy of bringing the body back involves identifying the producing subject (collective or individual) of a particular piece of knowledge.

Here it is essential to remember two things: firstly, as we have seen, from its solipsistic preference, different viewpoints are not taken into consideration by the ego cogito, whose truth arrogantly comes without parentheses. In this respect, Mignolo (2018) alerts to the dangers of "how truth without parentheses overrules the possibility of truth in parentheses, that is, living in a pluriversal rather than in a universal mode of existence." Secondly it is important to understand that decoloniality is not about inverting or reversing the hegemony of coloniality. As Mignolo (2018, p. 115) says, contrary to the claim that we need a new truth without parentheses, decoloniality is about "revealing that without truth in parentheses there are no 
solutions to the problems created by modern/colonial truth without parentheses".

This in turn brings two other things to the fore: one is that coloniality cannot simply be ended; the other is that the hegemonic knowledges of coloniality cannot simply be erased or eliminated as they constitute our thinking as subjects constituted by and implicated in coloniality (the bibliographies on which our thinking is based are western and Eurocentric). The knowledges of coloniality and the effects of their historical violence can at least be reduced and diminished when they are juxtaposed with other previously excluded knowledges in a pluriversality (VERONELLI, 2016), a transmodernity (DUSSEL, 2012) or an ecology of knowledges (SANTOS, 2007).

Before we delve into the double-twin aspects of chronological/historical vs. spatial/geographical, bringing the body back and marking the unmarked which, together with thinking communication otherwise, is essential to the triad IdentifyInterrogate-Interrupt, it may be of importance to address one of the foundational aspects of decoloniality which is that of colonial difference which arises from initial colonial encounters. It stems from Quijano's (2005) theory of social classification in which, beginning with and extending the colonial encounter between an invading European and a native other, the world population was deliberately classified by the European as superior or inferior, rational or irrational, civilized or barbarian, modern or traditional, human or sub-human. The category of race was later used to encapsulate and signify this colonial difference, now encoded as race and translated into a biological element at the service of domination, exploitation, and subjugation. That is how epistemology manipulatively creates ontologies as a way to justify the colonial/modern project and results in onto-epistemologies of coloniality:

The colonial difference operates by converting differences into values and establishing a hierarchy of human beings ontologically and epistemically. Ontologically, it is assumed that there are inferior human beings. Epistemically, it is assumed that inferior human beings are rational and aesthetically deficient. (MIGNOLO, 2009, p. 46)

What is then to be identified in the triad IdentifyInterrogate-Interrupt? Is it that easy to identify coloniality and 
its constituting fictions? What are some of the dangers in the rush to "be decolonial" by denouncing coloniality everywhere? One of the initial risks is to see coloniality as pertaining to others and not to the self. This can occur if location is not taken into account. If, coloniality as we have just seen refers to a complex and interconnected set of hierarchical relations stemming from the colonial difference, it is often difficult to identify on which side of the colonial difference, we are located as critical analysts. Together with the step of interrogation, identifying coloniality needs to depart from an awareness of one's location, or one's locus of enunciation. On which side of colonial difference is it located? Is it on the side that takes for granted that it, and its knowledges are the punto cero and all other to it is racialized as inferior? Or is one analyzing from a locus of enunciation that has been othered, negated, invisibilized and racialized?

This "self-decolonization" may be essential in order to perceive the location and discourses of coloniality that constitute both the analyst as subject and what is being analyzed and their interconnection. It can make the difference between wanting to emancipate a negated other and assimilate this other into one's own privileged (colonial) location (hence saving an other but keeping coloniality intact) and embarking on interrupting the hegemony of coloniality. As we shall see below, Dussel (2012) portrays this as either negating what coloniality negated (the existence, humanity, knowledge or language of an other) or negating the very process of negation and thus attempting to overcome the fundamental mechanism of exclusion in coloniality that Santos (2007) describes as the abyssal line. Dussel (2012) goes on by suggesting that we first identify with a negated, marginalized, peripheral other. For us in Latin America, decolonizing ourselves involves considering how and to what extent we are, as academics, negated, marginalized and peripheral in relation to Eurocentric coloniality in terms of our knowledges and languages? If we are not, to what extent are we, through our silence or inaction, perpetuating the colonial difference and coloniality?

The decolonial strategies we advocate here, that is, thinking communication otherwise, bringing back the body and marking the unmarked, contribute to the delinking from the universal rhetoric of Modernity and the neglect of local histories 
Departing from the premise that decoloniality is growing in popularity within contemporary Brazilian Applied Linguistics studies, this paper claims for a more performative decolonial praxis so as to prevent decoloniality from universality. In doing so, the text claims for thinking communication otherwise which, along with the notions of bringing back the body and marking the unmarked, constitute the necessary decolonial strategies for interrupting coloniality. A critical examination of The falling Sky: words of a Yanomami shaman, co-authored by Kopenawa and Albert (2013), is brought to the fore as illustrative of such a performative decolonial praxis which attempts to help language teacher educators and researchers to become attentive to socially-just-oriented educational agendas that claim to be culturally-sensitive whereas, in fact, they may be serving the purposes of a still prevailing colonial project.

\section{Three decolonial strategies}

Before we discuss the three decolonial strategies for the interruption of coloniality we propose in this paper - that is thinking communication otherwise, bringing the body back, and marking the unmarked - and how these unfold into the decolonial pedagogy present in Kopenawa's (2013) own experience as examined in the subsequent section, we find it relevant to retrieve Andreotti and Souza's (2017) criticisms against certain types of educational reforms.

By claiming that the all-encompassing term "critical thinking" needs to be deeply problematized as a pre-condition for understanding how different social and educational reform proposals operate, Andreotti and Souza (2017) propose a distinction between what they call "three problem spaces of critique", that is: soft reform of modernity, radical reform of modernity, and modernity beyond reform.

As explained by the authors, soft reform sees modernity as a well-succeeded, benevolent and sustainable system in which universal claims of knowledge founded on science and technology are taken as a premise for global development. By viewing colonization as a problem of exclusion in which inequality results from a "lack" of modernity, soft reform alternatives rest in "incorporation policies" with no structural changes (ANDREOTTI et al, 2019). As one can see, this type of 
reform somehow echoes assimilationist-oriented multicultural policies back in the 60 s and 70 s by which excluded individuals are legally protected within existing institutions whilst exclusion persists untouched in society.

Radical reform, in turn, brings a different perspective to modernity by acknowledging its flaws and limits towards more equitable and socially-just societies. As put by Andreotti and Souza (2017), radical reform sees inequality and exclusion as rooted in imperialist and colonial modern history. Marxistoriented, radical reform proposes a radical social transformation so as to prevent from hegemonic domination and exploitation. In doing so, empowerment, liberation, and agency of those marginalized and subjugated groups are key elements and should be fostered under critical pedagogy agendas.

By assuming that neither addition nor redistribution will change the pillars of this ever-lasting colonial system, 'beyond reform' policies place modernity as "inherently harmful, unsustainable, and irresponsible" (ANDREOTTI; SOUZA, 2017, p. 272) and acknowledges the fact that coloniality functions as this necessary condition for the maintenance of modernity, echoing Mignolo (2018, p. 109) when he asserts that "if coloniality is engendered by modernity, there cannot be modernity without coloniality; and there would be no coloniality without modernity. To end coloniality it is necessary to end the fictions of modernity". That being said, if coloniality is the dark side of modernity, then, it cannot be reformed if one simply acknowledges the co-existence of multiple epistemologies without changing the prevailing ontology of modernity (ANDREOTTI et al, 2019). While long-term alternatives to the alternatives are still under construction (SANTOS, 2018), 'beyond reform' policies might imply "walking out from dominant systems and institutions (e.g., the deschooling movement), investing in the creation of alternatives (e.g., Gaia education), hacking the system from within, or hospicing the system in order to learn from its mistakes and make only different mistakes in the future" (ANDREOTTI; SOUZA, 2017, p. 272).

That being said, the three decolonial strategies we advocate in this paper respond to the beyond reform type: Thinking communication otherwise involves going beyond a focus on dialogue and problematizing universal 
presuppositions about interlocutors in a dialogue, such as, they are equal and equally human, and that the language of the dialogue is complete, neutral, transparent and nonconflictual. Bringing the body back involves rejecting and going beyond the modern presupposition of universality as produced by the separation of body from mind, rationality from emotion, and universal from local. Marking the unmarked goes beyond the presupposition of universal normativity to unleash a plurality of possibly conflicting normativities.

By thinking communication otherwise in 'beyond reform' pedagogic proposals, we have in mind Santos' (1996) reminder for the need of emancipatory pedagogical projects that can put an end to the project of modernity that imposes cultural hierarchies and makes communication between cultures difficult. A means of exit from this situation, he suggests, is through intercultural translation. Firstly, however, Santos (1999) reminds us that the project of Eurocentric modernity is accompanied by an imperative of universality and homogeneity.

This imperative reflects the belief, dear to this modernity, that equality, freedom and citizenship, are unquestionably part of the emancipatory principle of social life. Santos describes the two social principles that embody this belief as the principle of emancipation, whose goal is equality and social integration, and the principle of regulation, whose goal is to control and administer. However, as Eurocentric modernity, over time, became entangled with capitalist development, there arose a contradiction between these two principles, which resulted in inequality and exclusion. As this entanglement damages the principle of emancipation, dear to modernity, it cannot be tolerated by the system, and the principle of regulation sets in to control and administer the contradiction. However, this principle of regulation considers, according to Santos (1999), universality and homogeneity as efficient means to control and guarantee equality, freedom and citizenship.

This concept of universalism, as an ideological means of control, may take two forms - anti-differentialist and differentialist. The first denies the existence of differences, imposes homogeneity and erases any basis for a comparison among differences. The second form of universalism operates by making differences absolute and hence impossible to 
compare. For Santos, both of these forms of universalism take the hegemonic culture as their basis for judgement; by doing so, both subjugate and control cultures that are different to the hegemonic. They are both examples of hegemonic culture putting others, and not itself, into parentheses. Given this hegemonic use of universalism, which also becomes an obstacle to communication between the excluded and excluding groups, Santos $(1996,2018)$ proposes the counterhegemonic decolonial and southern epistemological uses of intercultural translation and diatopical hermeneutics.

Here Santos' (1996) proposal of a pedagogy of conflict becomes relevant. This proposal comes in the wake of his denouncing of the massive and widespread use of the media in modernity and its persistent propagation of homogenizing and repetitive images of inequality and suffering. This repetition and homogenization decontextualizes and trivializes social injustices and suffering and presents them as banal, unchanging and impossible to transform. In the face of this, Santos calls for a pedagogy that may challenge this pasteurization of suffering by presenting and highlighting conflict and difference. This seeks to expose the learner to a heterogeneity of conflicting theories, practices and conflicting forms of commonsense. For this pedagogy of conflict to work, intercultural translation and one of its instruments - diatopical hermeneutics, need to be promoted and operated. Before this, however, Eurocentric universalism needs to be challenged:

There is no European universalism; there is rather a European foundational experience that, due to it overriding economic and military power, imposed itself on other foundational experiences existing in the world and thereby granted itself the prerogative of proclaiming its universal validity. (SANTOS, 2018, p. 39)

For Santos, Eurocentric universalism is challenged when the abyssal line of coloniality is challenged; as mentioned above, this is the line that is instituted through coloniality and the colonial difference and that separates beings, their knowledges and languages, into visible and of value on one side and not visible (but not inexistent either) and of no (or lesser) value on the other side. Once this line, together with the colonial difference, is successfully challenged, the previously 
invisibilized beings and knowledges become apparent together with the previously hegemonic beings and knowledges. Rather than inverting the colonial difference and rendering invisible, and of no value, the previously hegemonic beings and knowledges, the challenge to the colonial difference and the abyssal line proposes to interconnect all that was on both sides of the line into an ecology (SANTOS, 2007, 2018); it thus puts all knowledges, cultures, beings and languages equally in parentheses in a pluriversality.

Santos (2018, p. 38) is quick to establish that this unleashing of a pluriversality of knowledges is not a relativism. Relativism implies a strong element of objectivity and essentialism embedded in the presupposition that a plurality of perspectives consists of varying perspectives of 'the same thing'. This assumption of the unquestioned sameness of "the same thing" harks back to the imposition of a hegemonic perspective as the basis for construing an idea of the universal: who judges that it is 'the same thing' that is seen from multiple perspectives? On the contrary, the ecology of pluriversality that is unleashed is relational (BOURDIEU; WACQUANT, 1992) in the sense that, each element that constitutes it, exists as interconnected to the other elements, and each element is constituted, dynamically and continuously, through its interactions with the others.

There is no space for essentialism, substantialism or universalism here. This ecology thus represents a cacophony of disparate and conflicting cultures, knowledges and languages, each opaque to each other in the pluriversality. In order not to be overwhelmed by an excess of opacity, it is through intercultural translation, that communication may be established, and the cacophony may be rendered, minimally, mutually intelligible. As a means of thinking communication otherwise, intercultural translation (SANTOS, 1996) is based on four presuppositions: firstly, it needs to be recognized that the desire for universality implies a desire for hegemony (as exemplified by Eurocentric universalism), and this needs to be abandoned to perceive interconnectedness in a relational ecology; secondly, it requires the recognition that all cultures, languages, and knowledges are incomplete and in a constant process of becoming through interaction/relations with others. Therefore, a process of translation, rather than a relation between complete substances or totalities, must be seen as a relation between incompletenesses 
in which all participants gain or lose something; the third presupposition is that to facilitate 'communication otherwise', among the various possibilities that each culture presents, that which presents the greatest degree of openness to otherness and the greatest possibility of reciprocity must be chosen for translation; fourthly, intercultural translation requires a degree of curiosity (SANTOS, 2018, p. 33), which involves an impulse towards contact with alterity and newness.

As we have seen, the means for intercultural translation that Santos suggests, is diatopical hermeneutics, which he describes as having one leg in one culture and the other leg in the other culture. Besides the four presuppositions of intercultural translation, what diatopical hermeneutics requires, in order for its strategy of "communication otherwise" to function, is the downgrading of cultural premises to arguments. When held as a premise, something is presupposed as unquestionable and is used as anterior to, and a foundation of arguments. An argument, on the other hand, is made visible in the process of arguing and is open to and subject to change through persuasion and argumentation. Thus, in order to counter a desire for universalism and hegemony in intercultural communication, Santos suggests that in a diatopical hermeneutics, all premises should be downgraded to arguments and thus open to change, echoing Mignolo's (2018) claim towards a truth with parentheses. Moreover, Santos' conception of intercultural translation through diatopical hermeneutics approximates proposals of 'beyond reform' educational policies which similarly abandon hegemonic systems and institutions.

In the next section, we shall proceed to examine an example of a peripheral pedagogy that requires intercultural translation and diatopical hermeneutics. Before that, however, it is important to mention the risk one incurs here in objectifying such pedagogies; this includes the risk of recolonizing them, rather than contributing to their attempts at decolonization. As we have said at the outset, with Dussel and Mignolo, decolonial actions should ideally speak with, from and for and not about marginal knowledges and groups. Here, rather than objectifying, and thus reducing, their potency, we intend to potentialize it by showing their effective use not only of intercultural translation and diatopical hermeneutics, 
${ }^{1}$ From the original, "espanto e indignação" (SOUSA SANTOS, 1996, p 17) but also of the strategies of bringing the body back and marking the unmarked. Moreover, we hope to show how the chosen peripheral pedagogy also enacts the decolonial triad IdentifyInterrogate-Interrupt.

The concept of pedagogy that we are using here is already an enactment of intercultural translation that, as we have seen, requires, in its fourth presupposition, that "among the various possibilities that each culture presents, that which presents the greatest degree of openness to otherness and the greatest possibility of reciprocity must be chosen for translation". Thus, we have chosen to understand pedagogy in its widest sense as 'having the intention to disseminate knowledge for social change'; moreover, we consider the proposal we shall analyze as one of 'beyond reform'. As we have seen, Andreotti and Souza (2017, p. 272) define 'beyond reform' pedagogies as those that walk out from dominant systems and institutions, invest in the creation of alternatives, or hospice the system in order to learn from its mistakes and make only different mistakes in the future.

As Santos (1996) reminded us, we need 'pedagogies of conflict' which denaturalize hegemonic and homogenized/ universalized knowledges and denaturalize the trivialization of suffering in order to retrieve the possibility of "surprise with the unknown and indignance"1 in order to potentialize nonconformity and rebellion among learners; nonconformity and rebellion here are elements necessary for a decolonial pedagogy.

\section{Identify-Interrogate-Interrupt: keeping the sky from falling}

The example of 'beyond-reform' decolonial pedagogy that we shall examine is The falling Sky: words of a Yanomami shaman, co-authored by Davi Kopenawa and Bruce Albert (2013). Kopenawa, having identified the coloniality in the destruction of the forest and its effect on the indigenous peoples that live in it, including his own, seeks urgently to contribute towards the interruption of this coloniality through disseminating awareness of this destruction among the white Brazilian community, by interrogating it. Kopenawa's proposal also allows itself to be characterized as a pedagogy when framed by his shaman father-in law's appeal: 
The forest is alive. The white people persist in destroying it. We are dying one after another, and so will they. In the end, all of the shamans will perish, and the sky will collapse. Before it is too late," [...] "I want to talk to you about a time long ago when the animal ancestors transformed. Thanks to my shaman elders, I learned how to call them. I see them, I share life with them, and I listen to them.

You must hear me-time is short. (vii)

You must tell the white people that! They must know that we are dying one after another because of this evil smoke from the things they tear out of the ground!" This is what I am now trying to explain to those who will listen to my words. Maybe it will make them wiser? (KOPENAWA, 2013, p. 296)

The book consists mainly of three groups of interconnected narratives Becoming Other, Metal Smoke and The Falling Sky, besides a substantial account of how the book was compiled by the French anthropologist Bruce Albert. Kopenawa clearly follows the Identify-Interrogate-Interrupt strategy; however, the decolonial strategies enacted in the book may not appear in that order due to the fact that, in written form, the book is a compilation of oral exchanges between Kopenawa and Albert, his friend/anthropologist/co-author; the oral recordings were probably written and compiled in a different order to that in which they occurred.

Nonetheless, there are clear moments of identification of coloniality when Kopenawa describes the injustices and violence he suffers in his own process of attempting to assimilate and "become white" by migrating to urban centers in the Amazon. One of the most violent examples is when none of the white medical staff, at a medical outpost, warn him that the indigenous patient, whose room and food he shares, is suffering from terminal and contagious (especially to an indigenous person) tuberculosis; Kopenawa ends up contaminated and, as a result, spends a year recuperating, in isolation. Among other similar experiences, he begins to question if he can ever fulfill his desire to become white, reaches the conclusion that he cannot become white, unless it is to his detriment, and decides to interrogate and interrupt similar desires to become white among the young in his community: 
This is why I often tell the young people of our house now: You think that one day you may become White people? That is nothing but a lie! Do not believe that you merely need to hide in their clothes and display a few of their goods to become one of them! Believing something like that just tangles up your thought. You will wind up liking the cachaça better than the forest's words. Your mind will darken and finally you will die of it! It is true. (KOPENAWA, 2013, p. 219)

Kopenawa interrogates the coloniality of the dominant white community that believes that the Yanomami should be "civilized" and assimilated by implementing the presumption of universality and homogeneity that is operated by the social principle of regulation and control; this blatantly contradicts and damages accompanying social principle of emancipation. As we have seen above, this damage occurs when capitalist development crosses paths and becomes entangled with, the ideals of modernity. Modernity's claims to afford equality, freedom and citizenship to the indigenous communities like the Yanomami, gets caught in the undertow of capitalism and coloniality, resulting in inequality and exclusion for the Yanomami. Also, as we have seen above, as the principle of emancipation does not tolerate inequality and exclusion, the principle of regulation and control triggers, in reaction, the imposition of universality, especially in its anti-differentialist form, which, in an impulse to impose equality, denies the existence of differences and imposes homogeneity thus erasing any possibility for a comparison among differences.

As a result, cultural differences between the hegemonic and Yanomami cultures are eradicated in a move that establishes the universality and superiority of Eurocentric hegemonic culture; this indirectly justifies the eradication of the allegedly inferior indigenous culture. The lack of intercultural translation between the two cultures indicates various lacks on the part of the hegemonic culture of coloniality: besides the lack of the perception to think communication otherwise and embark on intercultural translation, there are the accompanying failures to abandon hegemonic universality (this universality was implemented by the principle of regulation and control); the failure to recognize the incompleteness and relationality of all cultures and values (hegemonic Eurocentric culture was used as the yardstick to judge indigenous culture as 
inferior); the failure to choose, among the available variations of the hegemonic culture, one which could be more open to the alterity of Yanomami culture (despite the vast academic tradition of anthropological knowledge available in Brazil; ironically, Brazil is home even to the work of Levi-Strauss, who established a strong tradition of Eurocentric anthropological thinking, open to indigenous alterity); and finally the failure to sustain a minimum of curiosity in indigenous culture.

As Kopenawa indicates constantly in his narratives, the forest is being destroyed (hence the falling sky) by capitalist development which incessantly sees the Amazon Forest as untouched resources (mining, agriculture, timber) to be exploited for profit. The coloniality of this posture lies clearly in its rejection, through colonial difference and the abyssal line, of other modes of conceiving nature, other than that of capitalism, that considers nature as profitable resources to be exploited:

Instead, our words were tangled up in ghost talk whose twisted drawings were propagated everywhere among white people. We don't want to hear that old talk about us. It belongs to white people's evil thoughts. I also want them to stop repeating: "What the Yanomami say to defend their forest is lies. It will soon be empty. There are only a few of them and soon they will all be white people! (KOPENAWA, 2013, p. 24-25)

Kopenawa, on the contrary, implements intercultural translation in the very intention of disseminating his thoughts. This represents, as we have said, not just a pedagogy, but a pedagogy of conflict as defined by Santos (1996) above, and a pedagogy of 'beyond reform'. It insists on confronting differing interpretations - that of "the white man" with that of the Yanomami; it insists on denaturalizing hegemonic "white" thinking in order to provoke 'surprise with the unknown' and indignation in his reader. Kopenawa's work goes beyond ethnography or auto-ethnography; it is an attempt to put knowledges - hegemonic and indigenous, into parentheses. Where he speaks to his reader/listener apparently as a biographic individual, recounting narratives of his personal experiences in dealing with urban culture and whites, he is in fact speaking as a collective being, a member of his community. 
And not just any member, but as an elder, and as a shaman. Therefore, he speaks as a legitimate representative of his community, one who has access to the shamanic knowledges, which are not available to anyone. Access to these knowledges, as Kopenawa describes in great detail, requires a long period of apprenticeship and the undergoing of often violent and cumbersome rituals.

The descriptions of this process of becoming a shaman, and having access to privileged knowledge, form a significant part of what may be called Kopenawa's strategy of intercultural translation through diatopical hermeneutics. As we have seen, an important aspect of diatopical hermeneutics is to facilitate communication, by downgrading unquestioned cultural premises, and transforming them into arguments. It is by doing this that Kopenawa, in his pedagogy, describes spirits and takes pains to explain the acquisition of knowledge, the use of the element yãkoana to achieve altered states of consciousness, and to facilitate communication with the spirit world; these explanations which are normally not shared with outsiders, may be seen as the down-grading of premises to arguments.

I had no other professor than Omama. It was his words, which came from my elders, that made me wiser. My words have no other origin. Those of the white people are so different. They are probably clever, but they badly lack wisdom. (KOPENAWA 2013, p. 13)

My wife's father, the great man of our Watoriki house at the foot of the Mountain of the Wind, had made me drink the powder that the shamans extract from the yãkoana hi tree. Under the effect of its power, I saw the spirits of the kopena wasps come down to me. They told me: "We are by your side and will protect you. This is why you will take this name, Kopenawa!" It is so. This name comes from the wasp spirits who absorbed the blood spilled by Arowë, a great warrior of the beginning of time. My father-in- law made their images come down and gave them to me with his breath of life. Then I was able to see them dance for the first time. (KOPENAWA, 2013, p. 19)

In these extracts, Kopenawa makes clear that, unlike modern western knowledge, which is characterized by rights of individual ownership and authorship, Yanomami knowledge is loaned. It belongs to the spirits and not to the 
human with whom they share it. The violent and cumbersome rituals are guarantees that those with whom the spirits share their knowledge are worthy of it. In fact, in terms of cultural translation and diatopical hermeneutics, Kopenawa engages in two levels of intercultural translation: at one level, he describes the translation-cum transformation that he undergoes in order to understand and be understood by the spirits:

The ground on this clearing is a vast mirror strewn with white down feathers, which scintillate in a blinding light. All this is both magnificent and so frightening! It is our image that the spirits carry away in order to set it to rights. First, they extract it from inside our body and put it down on their mirrors in the sky. Meanwhile, our skin, which has become so weak, remains stretched out on our house's plaza in the forest.

Then the spirits lose our thought and language in order to teach us theirs. Next, they make us learn the pattern of the forest so that we can see it like they do and protect it. The xapiri are superb and sparkling with light. They seem fragile but are very powerful. From their mirrors, they reveal the approach of epidemic fumes, evil beings, and storm wind spirits to us. White people do not know this. Yet this is how our elders have always become shamans. We are only following in their footsteps. (KOPENAWA, 2013, p. 84)

The figure of the mirror and one's personal image here, is significant to understand diatopical hermeneutics and cultural translation. Here communication/translation does not involve the simple transfer of meanings. As we have said, it involves the perception of incompleteness, openness to alterity, and the abandonment of a desire for hegemony and control; moreover, being relational and not relativistic, intercultural translation results in change through interaction, as the spirits do, when they carry away one's image, in order to transform it ("to set it to rights"), by placing it in a vast mirror in the sky. Then, the spirits interfere in the initiate's thought and language, in order to teach him theirs. Next, they teach the initiate the pattern of the forest, so that he can "see it like they do and protect it". Intercultural translation is shown here to be significant in approximating interlocutors between whom there had been no previous communication and indicates the transformation that these interlocutors undergo in the process. 
Here, we have the basis of what thinking communication otherwise can mean. In order for this communication to occur, besides the use of yãkoana, there are conditions that need to be satisfied to enable communication with the xapiri in the spirit world; these are not unlike the four conditions mentioned above of intercultural translation as specified by Santos (2018, p.85): "If you really want to see the xapiri and answer them, you must often drink the yãkoana. You must remain at rest in your hammock and stop eating and copulating without restraint. If so, the xapiri will be satisfied. If not, they will find you dirty and run away.".

Besides this communication/translation with the spirit world, the other level of intercultural translation in which Kopenawa engages, is between the indigenous Yanomami and the hegemonic white world. The already mentioned four conditions for intercultural translation, in this case, are also followed: firstly, Kopenawa abandons the desire for universality and hegemony; he is aware that his culture and people are powerless and marginalized by coloniality. From a hegemonic "our knowledge is worth more than yours", Kopenawa proposes an appeal to solidarity - "listen to what our spirits have to say and how our people and knowledge are suffering; it may help to save all of us from destruction". In terms of the second condition, of recognizing incompleteness, Kopenawa affirms that no human's knowledge is outstanding and permanent. The only worthy knowledge is that of the spirits of the forest. Humans come and go; the spirits of the forest remain. Also, the knowledge of these spirits is not self-sufficient; the spirits need human shamans to constantly update and disseminate their knowledge and communicate with them. In terms of the third condition, that is, the choice of a variant of the culture that permits greatest reciprocity and openness, Kopenawa uses the media discourse of the destruction of the forest and the environment; this connects with hegemonic discourses of climate change and environmental destruction. Lastly, in terms of the condition of curiosity, Kopenawa operates at two opposing levels: one, aimed at the young of his own and other indigenous communities, warns against the curiosity to become white and migrate to the urban districts; at another level, Kopenawa incites the curiosity of hegemonic white culture in the exotic, by making great use of devices of estrangement 
or defamiliarization, not only in the use of Yanomami words (yãkoana, xapiri, kãokãoma, etc), but also by describing rituals and spirits that stimulate the imagination of those in white culture who desire the exotic; Kopenawa thus turns this kind of reader into an audience for his call for solidarity and collective action.

As for diatopical hermeneutics, besides downgrading Yanomami cultural presuppositions from premises (the Yanomami are enrichened by the knowledges which only they obtain from the spirit world) to arguments (these knowledges help us to survive culturally but not physically), as we have mentioned above, Kopenawa enacts what Santos described as the basis of diatopical hermeneutics: he has one foot in each culture. It is perhaps only because Kopenawa lived in white urban communities, had contact with good and bad white people, and adopted certain customs of the whites that he is able to formulate his 'beyond reform' pedagogy of conflict:

It is true that today I still hide my penis in shorts. It is a habit I picked up with the people of Teosi when I was a child. It is also true that I know a little of the white people's language. Yet I only clumsily imitate it when I go to the city or talk to them in the forest. Then, as in the past, I try to be a werehe parrot and attempt to make myself understood. But as soon as I am alone with my people, my mouth closes itself to these strange words. They escape far from my mind, and my tongue hardens without being able to pronounce them. (KOPENAWA, 20213, p. 220)

'Becoming other' is a key term in Kopenawa's pedagogy of conflict and connects with the decolonial strategies of bringing the body back and marking the unmarked. For Kopenawa, 'becoming other' is used to refer to the loss of identity in both, a positive, and a negative manner. In its most common use in his narratives, it refers to the process of shamanic initiation in which a spiritual and bodily transformation needs to occur. This is initiated through the use of yãkoana and involves a symbolic/ psychic dilaceration and reconstruction of the body: "the spirits put me back together upside down" (KOPENAWA, 2013, p. 418). It signifies a positive loss-as-progression of a previous identity and the transformation into the more privileged identity of a shaman, now capable of communicating with the spirit world: "If you do not become other with the yãkoana, you can only live in ignorance" (KOPENAWA, 2013, p. 422). In its other, 
less frequent and more negative use, 'becoming other' refers to the loss-as-regression of one's cultural identity and values: "If we forgot the xapiri and their songs, we would also lose our language. Deep inside ourselves, we would become other. By imitating the white people, we will only succeed in becoming as ignorant and fearful as their dogs (KOPENAWA, 2013, p. 419). In both cases 'becoming other' is connected to language; in its positive use, it refers to the acquisition of a new language, a capacity to communicate with the spirits, and access to privileged knowledge. In the negative case it refers to the loss of one's own language and one's identity.

As a decolonial strategy, bringing the body back seeks to resist claims to universality, through which the western cogito separates not only mind and body, but also knowledge, from its producer, and from the context of its production. In order to undo this separation and the claim to universality, the strategy follows Dussel's (2012) injunction against Eurocentric universality, to situate and locate. This is a significant step towards challenging the abyssal line and colonial difference and unleashes the pluriversality of an ecology of knowledges, previously invisibilized by the hegemonic singularity that accompanies claims to universality. This strategy is followed closely by that of marking the unmarked, which reinforces the locality and situatedness of elements that claim to be unmarked, and thus universally normative. Marking the unmarked involves de-normatizing a self-proclaimed normativity. Both these strategies contribute to putting knowledges into parentheses.

Moreover, Dussel's decolonial strategy against universalism doesn't stop at situating and locating; it specifies, as a privileged location for decolonial action, the periphery of Eurocentric modernity. This is not merely to bring visibility to the marginalized and excluded, but to show the interconnection and relationality, or mutual constitution, that pertains between hegemonic centers and their peripheries. It was with this in mind that we chose to offer a decolonial reading of Kopenawa and Albert's The Falling Sky, and present it not as an ethnographic study, of a marginalized indigenous culture, but as an example of a decolonial pedagogy of conflict and one of 'beyond reform' that enacts a de-naturalization of suffering and a move towards social change through a critique 
of coloniality and a presentation of co-existing and conflicting knowledges.

In Kopenawa's pedagogy of The Falling Sky, he himself narrates his initial attraction to hegemonic urban white culture which sells itself as universal, and in which he can distance himself from his situatedness and locality, as a Yanomami from the forest, in order to become a seemingly better other. From the aggression, rejection, and ill treatment that he receives in contexts of hegemonic white culture, Kopenawa painfully perceives that he cannot abdicate from his body, his situatedness, and his identification as indigenous. He also perceives that he is othered when he feels the brunt of the coloniality of the hegemonic culture which attributes to itself a language and identity, as normative and universal, and excludes him on the basis that he is indigenous, of a 'local' identity, and a non-speaker of Portuguese. He experiences a body, marked by absence and invisibility, in contrast to the commanding presence of the 'white' hegemonic body.

In two specific violent events, Kopenawa is reminded of the insignificance attributed to his body and his symbolic locus of enunciation, in contrast to the universality (and greater value) of a white hegemonic body. In one, already mentioned above, Kopenawa is not warned by the white staff, at a medical outpost, of a blatant risk of being infected by tuberculosis, $\mathrm{He}$ ends up being infected: "I only wanted one thing: to be one of them" (KOPENAWA, 2013, p. 216). The second case involves the un-named white driver of the Demini FUNAI outpost, who treats Kopenawa and his family badly and offends their food with disgust. Whereas, in the first case, Kopenawa was still unversed in the coloniality of the ways of the white man, in the second case, armed by experience, he physically, decolonially, reacts: "You think you can act like the chief here, but you are not an elder. You are just a know-nothing" (KOPENAWA, 2013, p. 250).

There is a clear difference between the two events. In the first, Kopenawa is still under the spell of the appeal of the universal, and is seeking distance from the local, and his origins. In the second event, Kopenawa has become wise to the impossibility of universality and bodilessness and has recuperated pride in his locality and identity. It is this that gives him confidence and voice and permits him to react violently, 
identifying, interrogating and interrupting coloniality all at once. He has successfully brought the body back into his thinking, attributing locality both, to himself and to the 'whites' around him and, in so doing, he, symbolically and discursively, marks the unmarked, and diminishes the effect of their claimed authority.

Similar to what Santos (1996) proposed for a pedagogy of conflict, Kopenawa recovers the ability to be surprised/taken aback and to express indignance, on his part and on that of his reader. As already mentioned, the decolonial strategies of bringing the body back and marking the unmarked are inspired by Dussel's call for a proclamation of locality and situatedness in the periphery of modernity as the privileged site for decolonial action. This, however, raises the question of whether this privilege, attributed to locality and the periphery, against the universality of coloniality, configures a new essentiality and universality. Alcoff (2012) thinks not. She reminds us that Dussel, like much of decolonial theory (including the strategies of bringing the body back and marking the unmarked), specifically locates his ideas; this location and marking of situatedness forestalls, in Alcoff's view (2012, p. 67), accusations of absoluteness or infallibility aimed at such decolonial proposals. Moreover, the fact that such proposals not only emphasize, spatially, their location, but also situate their claims historically, indicates that they are open to, and foresee, future transformation.

Finally, in relation to 'beyond reform' pedagogies, that abandon dominant systems and institutions, invest in the creation of alternatives, hack the system from within, or hospice the system in order to learn from its mistakes and make only different mistakes in the future, Kopenawa's pedagogy exhaustively attends to these criteria; it abandons the once perceived desirability and progressiveness of both, the hegemonic white system and Yanomami culture; both stand to lose if they don't reflect on their mistakes. By doing this, he hospices both cultures on their way to extinction, learning from their mistakes and not eliminating the possibility of making other mistakes in a future that remains at risk for both the parties involved. As an expression of his own, previously silent voice, Kopenawa's pedagogy exercises democratic agency, but with no certainties or guarantees. 
By critiquing what he perceives as the coloniality of white culture and the subalternity of Yanomami culture, Kopenawa's pedagogy, like other 'beyond reform' pedagogies, challenges certainties and essences; by showing the persistence and sophistication of Yanomami shamanic traditions, Kopenawa attributes positivity to his marginalized culture but he also highlights its vulnerabilities; its sophistication is not perceived or appreciated by many Yanomami themselves. Most of all, Kopenawa's pedagogy points to the importance of relationality in decoloniality: if co-existence is not valorized, all those concerned are at risk.

Besides proclaiming the decolonial strategy of locating oneself in, and speaking from, the margins, Dussel also elaborates the need for those subjugated by coloniality to initially negate the negation attributed to their existence by the hegemonic center; this should then be followed by an overcoming of the whole process of negation. Though he painstakingly fulfills the first criterion, by negating coloniality, Kopenawa perhaps more realistically than Dussel, doubts whether he will live to see the overcoming of the process of negation itself:

In any case, even if they do not listen to my words while I am alive, I am leaving the drawing of these words on this paper skin so that their children and those who are born after them can one day see and understand them. Then they will discover the thought of the Yanomami shamans and know how much we wanted to defend the forest. (KOPENAWA, 2013, p. 411)

\section{The de-universalizing of educational agendas}

Decoloniality is recently growing in popularity in contemporary Brazilian Applied Linguistics research. If on the one hand, spreading the seeds of decoloniality is undoubtedly a very positive fact that contributes to the widening of perspectives as well as the voicing of global south epistemologies, on the other the burgeoning reference to decolonial thought in recent academic research as well as global and local educational policies brings the need to a deeper critical scrutiny of what is at stake when the popularity around a concept, idea or scholarship runs the risk of rendering them oversimplified, overgeneralized, naively misused or, in some 
cases, even manipulatively used. Influenced by a geo-bodypolitics of knowledge (MIGNOLO, 2007), the kind of critical scrutiny we propose implies, first and foremost, an emphasis on enunciation. To Mignolo (2018, p. 159), focusing on the enunciation and paying attention to the actors, institutions, and languages allows us to see who is behind the scene, or, in his words, "[...] who is manipulating the marionettes".

This paper wishes to reassert how decolonial studies have fought against the universal fictions of modernity that reject the value of local modes of knowing and being; secondly, it also reasserts how decolonial thought, which has emphasized different local cultural systems to the detriment of the past five hundred years of a singular global history, is incompatible with any attempt towards normativity, even if it tries to replace a previous normativity traversed by coloniality. In short, there is no room for any universal or a priori way of decolonizing. Or, at least, there cannot be any room for universal and prescriptive ways of addressing a decolonial-oriented educational agenda. In this respect, Mignolo's recent words are worth retrieving:

People organising themselves all over the world to delink from the fictions of modernity and the logic of coloniality find the vocabulary and the narratives that afford them affirmation; they are delinking from modernity/coloniality to relink with their own memories and legacies, thereby securing modes of existence that satisfy them. These modes of existing cannot be thought of as uni-global, uni-form, homo-geneous. All these claims are modern imperial claims: uniformity according to global designs intending to homogenise the planet. That is over. Decoloniality is neither a 'new' nor a 'better' global design that will supersede previous ones. (MIGNOLO, 2019, p. 12)

Why such concern with universality in our claim towards de-universalizing decoloniality? This paper is a call for us to spend the necessary time to appreciate decolonial theory before/ together with these recent attempts to implement decolonialoriented pedagogical practices. In this respect Dussel's (2012, p. 47) hermeneutic time as a strategy of resistance is worth retrieving: "In order to resist, it is necessary to mature. The affirmation of one's own values requires time, study, reflection, a return to the texts or symbols and constitutive myths of one's culture." 
That being said, along with the theoretical criticisms against universality within decolonial thought come the need to theorize and perform decoloniality in which this exercise of praxis is understood as practice with conceptual reflection. Since this decolonial performative praxis gives greater emphasis on location, it brings bodies back while contributing to the interruption of unmarked-ness in a communicative process whose cultural translation is founded on opacity, friction, complexity.

The critical examination of The falling Sky: words of a Yanomami shaman is the very performative decolonial praxis we advocate in this paper and turns to be a potential pedagogy for those willing to understand decoloniality in depth. Out of the many lessons learned with Kopenawa's intercultural translation we pinpoint: i) the interrogation of the other as well as the interrogation of ourselves; ii) the acknowledgment of incompleteness and relationality (never relativism); iii) the downgrading of premises and their transformation into arguments.

Bearing in mind that many of us work as faculty members in the areas of Applied Linguistics and Language Education, it becomes paramount to approach Kopenawa's lessons in our métier. In order not to fall into the trap of methodization, a set of critical questionings instead of prompt examples will be posed in relation to contemporary educational agendas so as to invite readers to perform decoloniality while they read educational proposals that claim themselves to be socially-justoriented and culturally-sensitive, whereas, in fact, they may serve the purposes of a colonial project.

Take the example of the UNESCO educational agendas that have widespread reach and prominent reference. Despite the fact that they often evoke a concern with ethics, citizenship, democracy, inclusion, and plurality, what lies below the surface is that universality still constitutes the warp and weft of many educational reports and guidelines, responding, thus, to the soft reform type as presented above. All this besides the obvious coloniality that in the case of the Delors Commission Report, the commission was lead by Delors, who had been President of the European Commission and a Minister of Finance in the French government. 
${ }^{2}$ The well-known pillars refer to learning to know, to do and to be and to live together (taken from UNESCO. Learning: The treasure within. Report to UNESCO of the International Commission on Education for the

Twenty-first Century. Paris: UNESCO, 1996.
Echoing the four pillars in the Delors Commission Report $\mathrm{t}^{2}$ by narrowing them down into three domains of learning - cognitive, socioemotional and behavioral - the UNESCO Global Citizenship Education (UNESCO, 2015) aims at developing recognition and appreciation of difference and multiple identities, attitudes of care and empathy for others and the environment, respect for diversity, values of fairness and social justice, among others. If on the one hand the document is discursively in tune with the "multi/pluri turn" - with which one would seldom dare to be against, making the persuading proposal quite politically correct - on the other, it is founded on western values universally assumed as the pre-condition towards "a more inclusive, just and peaceful world" (UNESCO, 2015, p. 15).

This is evident, for instance, when the document conceives of global citizenship as "a sense of belonging to a broader community and common humanity" (UNESCO, 2015, p. 14) and presupposes the notion of global as positive and beneficial to all. As a matter of fact, back in the 1990s, despite acknowledging the tensions between the global and the local, the Delors Report (UNESCO, 1996) had stated that people needed (our emphasis) to gradually become world citizens without losing their roots. Thus, the UNESCO goal towards a "common humanity" seems more in line with the replication of a set of universal principles and values as well as a priori established learning objectives in different communities and countries and less related to the recent decolonial debates on commonality, pluriversality, epistemic pluralism or the ecology of knowledges (DUSSEL, 2012; SOUSA SANTOS, 2007, 2018 to name a few).

By echoing modern premises that view progress and development as strongly connected to western knowledge production, the document responds to the soft reform type as global south developing countries are the ones to incorporate the world of science and technology under "cultural adaptation and the modernization of mentalities" (UNESCO, 1996, p. 13). The document brings a concern in relation to how educators and policy-makers all over the world may face difficulties and constraints. Nonetheless, it becomes a salvationist educational agenda by assuring countries that such proposal can be implemented "even with limited resources 
or in difficult circumstances". Existing social problems are acknowledged. However, there is neither the questioning of social, political, economic and epistemic structures nor a selfimplicated criticism with regards to where they are rooted for western universal values along with the $a$ priori learning objectives that are introduced as the way out. That being said, the UNESCO educational agenda reverberates the punto cero by not abdicating from its global north epistemic privilege, assuming, thus, that different local cultural systems, with their own modes of being and knowing, are deficient and need to adjust to universal solutions if they wish to thrive. According to Andreotti and Souza:

Typical soft reform research questions tend to see the status quo as inherently benevolent and universally desirable, while seeing the Other as deficient or lacking. Questions are formulated in instrumental ways with a view to support modern institutions to provide the Other with access to the dominant system as a remedy for his/her lack. (ANDREOTTI; SOUZA, 2017, p. 273)

The discussion brought by Andreotti and Souza (2017) goes hand in hand with Walsh's problematization on the notion of interculturality. Extensively used by many scholars from different research areas, ranging from philosophy, education, and decolonial thought, the concept soon emerged in many global and local language education agendas leading us to claim that some caution is made necessary in relation to who/ which agenda makes use of the concept and at the service of what this agenda is designed. Walsh (2007; 2012), then, points to three distinct perspectives to interculturality whose understandings differ in relation to different contexts and sociopolitical interests, that is to say, a relational perspective; a functional perspective; and a critical perspective.

The relational perspective operates under the acknowledgement of exchange between cultures, peoples, practices, ways of knowing, values and traditions in which equal and unequal conditions are made present. In other words, this perspective limits the notion of interculturality as contacts between different cultural and ethnic groups. To Walsh (2007; 2012), this fails to acknowledge that cultural difference, marked 
3 "[W]hen the word interculturality is used by the State in official discourses, the meaning is equivalent to multiculturalism. The State wants to be inclusive, reforming, to maintain its neoliberal ideology and the primacy of the market. But, in any case, it is important to acknowledge the reforms that can be carried out through state policies. Instead, the intercultural project from the perspective of indigenous movements is saying something else; it is proposing transformation" (our translation). by asymmetrical power relations, is structurally-based. It fails to acknowledge colonial difference. In the words of Walsh:

[C]uando la palabra interculturalidad la emplea el Estado en el discurso oficial, el sentido es equivalente a multiculturalidad. El Estado quiere ser inclusivo, reformador, para mantener la ideología neoliberal y la primacía del mercado. Pero, en todo caso, es importante reconocer las reformas que se pueden realizar a través de las políticas de Estado. En cambio, el proyecto intercultural en el discurso de los movimientos indígenas está diciendo otra cosa, está proponiendo una transformación. (WALSH, 2002a, p. 26 apud WALSH, 2007, p. 56) ${ }^{3}$

Though this perspective calls itself relational, it understands this notion as contact; it may easily be understood as contact between two complete and autonomous cultures, more than the incompleteness and mutual constitutionality that are present in Santos' concept of relationality in interculturality.

The second, functional perspective approaches interculturality from the issue of inclusion, resembling the liberal notion of multiculturalism which attempts to foster the promotion of dialogue, conviviality, and tolerance. Like the former, the functional perspective does not acknowledge that social and cultural inequality is a consequence of the existing system. On the contrary, it places the onus to adjust and thrive on different ethnic individuals and group minorities and is thus similar to older proposals of assimilation. Added to this limitation is the prevailing inconsistent and top-down mindset in both perspectives as debates often talk about but seldom talk with indigenous and black populations, echoing, thus, traces of the coloniality of being in which those placed at the other side of the abyssal line (SOUSA SANTOS, 2007) turn out to be objectified. In relation to Santos' conditions for intercultural translation, functional interculturality does not conform to the condition requiring the abdication from hegemony; on the contrary, it firmly re-affirms the existing hegemony

Contrary to the limitations of both perspectives, Walsh advocates in favor of critical interculturality as the only perspective that questions the colonial traces in existing capitalist systems. Within such a perspective, different individuals and communities are not the ones to adjust, but 
rather, it is the hegemonic institutional structures that need to be radically transformed towards a novel epistemic, ethical, political and social project in the reimagining of humanity. It is within this perspective of critical interculturality that decolonial thought resides bearing in mind that if one wishes to delink epistemically, one has to go beyond benevolent understandings of cultural difference and implicate themselves in their own critical questioning. Walsh's critical interculturality in this respect is not dissimilar to Santos' intercultural translation.

Inspired by Kopenawa's pedagogy, in our decolonial performative praxis towards de-universalizing decoloniality, we propose a set of critical questionings: When faced by a critical reading of a certain educational agenda that clashes with our previous views, do we consider our own knowledge as incomplete and relational? Do we also place the knowledge posited by such an agenda as incomplete and relational, and thus attempt to break with its illusion of universality? Do we perceive whether a proposed agenda affirms its hegemony or allows its hegemony to be positively challenged? When we interrogate the values, perceptions, knowledges within educational agendas, do we interrogate the values, perceptions, knowledges of our own? Do we see ourselves as implicated with the fictions of coloniality and modernity? Are we able to recognize our silenced voices and the positivity of our agentive selves while we take the courage to challenge the mainstream? Are we able to perceive our role as instruments of coloniality in silencing others and impeding their agency? Once we realize that certain educational agendas turn their arguments into universal premises despite their claims for pro-inclusion and pro-diversity, do we take them as premises or as arguments? If so, which other arguments are taken into account so as to pay justice to pluriversality? To what extent can we valorize and take advantage of where we are located and its educational needs and resources in responding to the previous questions?

\section{In conclusion}

Acutely aware that there is no foreseeable end to coloniality, and therefore to decolonial thought, the time has come to draw our discussion to a close. As we have seen, the three decolonial strategies of thinking communication 
otherwise, bringing the body back and marking the unmarked involve putting all knowledges into parentheses, unleashing a previously suppressed pluriversality, and using the perception of relationality and interconnectedness to engage intercultural translation. We have critically walked through two pedagogical proposals that seek pluriversality by putting and how they confront the task, if at all, of putting knowledge in parenthesis. At the end of the day, decoloniality ultimately involves hospicing the dying system of modernity and its underside, coloniality. However, as Kopenawa's words indicate, this unfortunately does not foresee merely the death of coloniality as a corollary. If coloniality, through the capitalism that currently sustains it, results in the exhaustion of nature and the environment, it also promises to eradicate life in general and thus the sky shall fall. Ailton Krenak, the indigenous philosopher, has recently shown (KRENAK, 2019, p. 32) how the magical belief in keeping the sky suspended above recurs in several indigenous cultures. This cultural logic proclaims that in order to keep the sky from falling, communities have to collectively and constantly invest energy to keep their rituals and knowledges alive. These rituals and knowledges, considered crucial for sustaining life, and thus crucial not only in forming subjectivity, but also in stimulating agentivity, must resist coloniality. Krenak sees the capitalistic desire of coloniality to consume nature as inseparable from its desire to consume, for profit, subjectivities, both hegemonic and marginal. This flags the pressing need for decolonial pedagogies to keep the sky from falling for everyone. After all, it is the sky that connects us all, hegemonic or peripheral and it is the sky that symbolizes relationality; it is this relationality that spells the impossibility of decolonizing others without decolonizing the self. 


\section{REFERENCES}

ALCOFF, Linda. Enrique Dussel's Transmodernism. Transmodernity: Journal of Peripheral Cultural Production of the Luso-Hispanic World, California, v. 1, n. 3, p. 60-68, 2012. Available at https://doi.org/10.5070/T413012882. Accessed: Jun 24, 2021.

ANDREOTTI, Vanessa; STEIN, Sharon; SIWEK, Dino; CARDOSO, Camilla; CAIKOVA, Tereza; PATAXÓ, Ubiracy; PITAGUARY, Benicio; PITAGUARY, Rosa; HUNI KUI, Ninawa; JIMMY, Elwood. Sinalizando rumos a futuros decoloniais: observações pedagógicas e de pesquisa de campo. Sinergias diálogos educativos para a transformação social, Portugal, n. 9, p. 9-28, 2019. Available at http://www.sinergiased.org/index.php/ revista/item/224-sinalizando-rumo-a-futuros-descoloniaisobservacoes-pedagogicas-e-de-pesquisa-de-campo. Accessed: Jun 24, 2021.

ANDREOTTI, Vanessa; SOUZA, Lynn Mario Trindade Menezes. Critical education and Postcolonialism. PETERS, Michael A. (ed.). Encyclopedia of Educational Philosophy and Theory. Singapore: Springer, p. 269-775, 2017.

BOURDIEU, Pierre; WACQUANT, Lois. An Invitation to Reflexive Sociology. Cambridge: Polity Press, 1992.

CASTRO-GÓMEZ, Santiago. La Hybris del Punto Cero: ciencia, raza e Ilustración en la Nueva Granada (1750-1816). Bogotá: Editorial Pontificia Universidad Javeriana, 2005.

DUSSEL, Enrique. Europe, Modernity, and Eurocentrism. Nepantla: Views from South, v. 1, n. 3, p. 465-478, 2000. Available at: https://muse.jhu.edu/article/23901/pdf. Accessed: Jun 24, 2021.

DUSSEL, Enrique. Transmodernity and Interculturality: An Interpretation from the Perspective of Philosophy of Liberation, Transmodernity: Journal of Peripheral Cultural Production of the Luso-Hispanic World, v. 1, n. 3, p. 28-59, 2012. Available at: https:// doi.org/10.5070/T413012881. Accessed: Jun 24, 2021. 
GROSFOGUEL, Ramón. The structure of knowledge in westernized universities: epistemic racism/ sexism and the four genocides/ epistemicides of the long 16th century. Human Architecture: Journal of the Sociology of Self-Knowledge, v. XI, n.1, p. 73-90, 2013. Available at: https://www.okcir.com/product/ journal-article-the-structure-of-knowledge-in-westernizeduniversities-epistemic-racism-sexism-and-the-four-genocidesepistemicides-of-the-long-16th-century-by-ramon-grosfoguel. Accessed: Jun 24, 2021.

KOPENAWA, Davi.; ALBERT, Bruce. The Falling Sky: words of a Yanomami shaman. Cambridge MA: Belknap Press of Harvard University Press, 2013.

KRENAK, A. Ideias para adiar o Fim do Mundo. São Paulo, Companhia das Letras, 2019.

MIGNOLO, W. Coloniality: The Darker Side of Modernity. In: BREITWIESER, Sabine; KLINGER, Cornelia; MIGNOLO, Walter (ed.). Modernologies: Contemporary Artists Researching Modernity and Modernism. Barcelona: MACBA, 2009, p. 39-49.

MIGNOLO, W. The invention of the Human and the three pillars of the colonial matrix of power: racism, sexism, and Nature. In: MIGNOLO, Walter; WALSH, Catherine. On decoloniality: concepts, analytics, praxis. Durham and London: Duke University Press, 2018, p. 153-176.

MIGNOLO, W. Coloniality is far from over, and so it must be decoloniality. MASP Afterall. São Paulo: Museu de Arte de São Paulo Assis Chateaubriand, 2019, p. 1-14. Available at: https:// masp.org.br/uploads/temp/temp-g6OIeV2haQPcq82qQDAR. pdf. Accessed: Jun 24, 2021.

QUIJANO, A. Colonialidade do poder, eurocentrismo e América Latina. In: A colonialidade do saber: eurocentrismo e ciências sociais, perspectivas latinoamericanas. Buenos Aires: CLACSO, 2005, p. 117-142.

SANTOS, Boaventura de Sousa. Para uma Pedagogia do Conflito. In: SILVA, Luis Heron da (Org.) Novos mapas culturais, novas perspectivas educacionais. Porto Alegre: Sulina, 1996, p.1533. 
SANTOS, Boaventura de Sousa. A construção multicultural da igualdade e da diferença. Oficina do CES - Centro de Estudos Sociais. Coimbra, Working paper 135, 1999. Available at: https:// ces.uc.pt/publicacoes/oficina/ficheiros/135.pdf. Accessed: Jun 24, 2021.

SANTOS, Boaventura de Sousa. Beyond Abyssal Thinking: From Global Lines to Ecologies of Knowledges. Review, v. 30, n. 1, p. 45-89, 2007. Available at: https://www.jstor.org/stable/ pdf/40241677.pdf?refreqid=excelsior\%3A85d5af5e7035131cc2d 7640455c1da95. Accessed: Jun 24, 2021.

SANTOS, Boaventura de Sousa. The end of the cognitive empire: the coming of age of Epistemologies of the South. Duke University Press: Durham and London, 2018.

SOUZA, Lynn Mario Trindade Menezes. Decolonial Pedagogies, Multilingualism and Literacies. Multilingual Margins, Western Cape, ZA, v. 6, n. 1, p. 9-13, 2019a.

SOUZA, Lynn Mario Trindade Menezes; MARTINEZ, Juliana; FIGUEREDO, Eduardo. “Eu só posso me responsabilizar pelas minhas leituras, não pelas teorias que eu cito": entrevista. Dossiê Especial FICLLA - Revista X , Curitiba , v. 14, n. 5, p. 05-21, 2019b Available at: http://dx.doi.org/10.5380/rvx.v14i5.70381. Accessed: Jun 24, 2021.

UNESCO. Global Citizenship Education: Topics and Learning Objectives. The United Nations Educational, Scientific and Cultural Organization, 7, France, 2015, 71 pages.

VERONELLI, Gabriela. Coalitional Approach to Theorizing Decolonial Communication. Hypatia, [S.l.], v. 31, n. 2, p. 404420, 2016. Available at: https://doi.org/10.1111/hypa.12238. Accessed: Jun 24, 2021.

WALSH, Catherine. Interculturalidad y colonialidad del poder: un pensamiento y posicionamiento "otro" desde la diferencia colonial. In: CASTRO-GÓMEZ, Santiago; GROSFOGUEL, Ramón. El giro descolonial: Reflexiones para una diversidad epistémica más allá del capitalismo global. Bogotá: Siglo del Hombre 
Editores; Universidad Central, Instituto de Estudios Sociales Contemporáneos y Pontificia Universidad Javeriana, Instituto Pensar, 2007, p. 47-62.

WALSH, Catherine. Interculturalidad y (de)colonialidad: perspectivas críticas y políticas. Visão Global, Joaçaba, v. 15, n. 1-2, p. 61-74, 2012. Available at: https://portalperiodicos.unoesc. edu.br/visaoglobal/article/view/3412. Accessed: Jun 24, 2021.

\section{RESUMO}

\section{Desuniversalizando o decolonial: entre parênteses e céus em queda}

Partindo da premissa de que o conceito de decolonialidade tornou-se tema frequente na Linguística Aplicada brasileira contemporânea, este artigo advoga em favor de uma práxis decolonial performática de modo a se prevenir que a decolonialidade irrompa em universalismos. Para tanto, o artigo inicia com algumas teorizações acerca da decolonialidade, com ênfase à tríade prevista em qualquer exercício decolonial, qual seja, a tarefa de IdentificarInterrogar-Interromper a colonialidade. O texto advoga em favor de uma comunicação outra, que, somada às noções de trazer o corpo de volta e marcar o não marcado, constituem estratégias decoloniais fundamentais para a interrupção da colonialidade. A discussão das estratégias é seguida por uma análise crítica da obra The falling Sky: words of a Yanomami shaman, de Kopenawa e Albert (2013), como exemplo de pedagogia decolonial que nos ajuda, na condição de pesquisadores e formadores de professores de linguas, a nos tornarmos mais alertas acerca de agendas educacionais afeitas à justiça social e à interculturalidade mas ainda alicerçadas em projetos coloniais.

Palavras-chave: Performance decolonial. Desuniversalização. Pensar uma outra comunicação. 
Ana Paula Martinez Duboc é Doutora pelo Programa Estudos Linguísticos e Literários em Inglês (Universidade de São Paulo - Brasil), tendo realizado parte de sua pesquisa na University of Manitoba, Winnipeg, Canadá. Atualmente, é professora de Metodologia do Ensino de Línguas Estrangeiras na Faculdade de Educação da USP. Seus interesses de pesquisa abrangem estudos da linguagem e letramentos, educação linguística, políticas educacionais, formação de professores de línguas, letramento crítico e decolonialidade. Coordena o ELCo Grupo de Estudos Educação, Linguagem e Colonialidade.

Lynn Mario Trindade Menezes de Souza é Doutor em Comunicação e Semiótica pela PUC-SP e Livre-Docente pela USP. Atualmente é Professor Titular Sênior do Departamento de Letras Modernas da Universidade de São Paulo, onde atua nas áreas de Linguística Aplicada, Teorias de Letramento e Teorias Pós Coloniais e Decoloniais. É membro do Scientific Advisory Board do Center for Multilingualism across the Lifespan da University of Oslo, Noruega, e membro do Think Tank: Rethinking Multilingualism and Being Human da University of the Western Cape, Cape Town, África do Sul. 